\title{
Bożena Śmiałkowska*
}

\section{WSPOMAGANIE PROCESÓW OCENY I WYBORU STRATEGII FIRMY ZA POMOCA ADAPTACYJNEJ HURTOWNI DANYCH}

\begin{abstract}
Streszczenie
Procesy definiowania strategii firmy i monitorowania wyników z jej realizacji są procesami złożonymi, wymagającymi dostępu do odpowiednich wiarogodnych danych. Z punktu widzenia systemów komputerowego wspomagania tych procesów szczególne znaczenie mają hurtownie danych, ze względu na ich temporalny i zorientowany przedmiotowo charakter. W artykule zaprezentowano model adaptacyjnej hurtowni danych, która wyposażona $\mathrm{w}$ mechanizmy nadążnego dopasowania tej hurtowni do zmiennych potrzeb informacyjnych firmy umożliwi ocenę bieżącego stanu realizacji strategii firmy oraz prognozowanie scenariuszy biznesowych i skutków ewentualnej zmiany.
\end{abstract}

Słowa kluczowe: hurtownia danych, wspomaganie zarządzania strategią firmy

\section{Wprowadzenie}

Procesy tworzenia, monitorowania i weryfikacji strategii firmy należą do sfery analityki systemowej, która polega chociażby na dostarczeniu odpowiedzi na takie pytania, jak: Czy możliwe jest przejście firmy z jednego stanu do innego, a jeśli tak - to kosztem czego lub jaką drogą? Jaki jest stan bieżący firmy w ujęciu systemowym? i dlaczego tak jest? Jak było, a jak być powinno?

Aby ułatwić procesy tworzenia, monitorowania i weryfikacji strategii firmy niezbędny jest dostęp we właściwym czasie do wiarygodnych, zintegrowanych i często uwarunkowanych historycznie informacji (danych), za pomocą których możliwa staje się ocena realizacji bieżącej strategii firmy oraz prognozowanie

${ }^{*}$ Bożena Śmiałkowska, dr hab., Zachodniopomorski Uniwersytet Technologiczny w Szczecinie, Wydział Informatyki, Katedra Inżynierii Systemów Informatycznych, e-mail: bsmialkowska@wi.zut.edu.pl 
przyszłych scenariuszy biznesowych wynikających z modelowanej (nowej) strategii firmy, gdy dotychczasowa strategia powinna być skorygowana.

Jedną z klas systemów, które wspomagają procesy podejmowania decyzji strategicznych są hurtownie (magazyny) danych (Data Warehouse). Dzięki wbudowanym w nich mechanizmom możliwy jest nie tylko dostęp do zintegrowanych danych z różnych obszarów działalności firmy, ale również przetwarzanie analityczne (On-line Analytical Processing - OLAP), eksploracja danych (Data Mining - DM), tzw. drążenie danych (Data Drilling - DD), odkrywanie (pozyskiwanie) wiedzy (Knowledge Discovery - KD) z danych oraz gromadzenie tej wiedzy w formie nowych źródeł danych po to, by wspomagać procesy podejmowania decyzji, zwłaszcza na szczeblu strategicznym. Tworzenie hurtowni danych w firmie to proces złożony i kosztowny. Wymaga nie tylko odpowiednich mechanizmów wspomagających podejmowanie decyzji, zwłaszcza gdy te decyzje dotyczą strategii firmy, ale również wyboru odpowiedniego modelu danych. I tak, dane zgromadzone w hurtowni danych dotyczą przeszłości (historii funkcjonowania firmy), a strategia i prognozowanie działań biznesowych dotyczą przyszłości. Im ta przyszłość jest dalsza od teraźniejszości i przeszłości, tym użyteczność danych zgromadzonych w hurtowni, w procesie budowy scenariuszy, zwykle jest mniejsza. Oznacza to, że użyteczność danych zgromadzonych w hurtowni jest zmienna w czasie. Ponadto w firmie powstają również nowe źródła danych, które mogłyby w pełniejszy sposób wspierać ocenę realizacji bieżącej strategii firmy i proces generowania scenariuszy biznesowych, które umożliwią prognozowanie skutków planowanych zmian strategicznych w firmie. Omówione przesłanki dowodzą, że hurtownia danych nie tylko powinna wspomagać procesy oceny i wyboru strategii firmy w jej biznesowym otoczeniu, ale również wspierać zmienne w czasie potrzeby informacyjne wynikające $\mathrm{z}$ tych procesów. Powinna dostosowywać się (adaptować) do nowych możliwości (np. nowe lub zmienione źródła danych) i potrzeb użytkowników. Koncepcję takiej hurtowni danych przedstawiono w kolejnym rozdziale.

\section{Model adaptacyjnej hurtowni danych}

Istotą adaptacyjnej hurtowni danych (AHD) są zawarte w niej mechanizmy nadążnego dopasowywania się do zmiennych potrzeb informacyjnych procesów oceny i wyboru strategii firmy. Oznacza to, że w podstawowych strukturach hurtowni danych powinny być przechowywane takie dane, które określają założoną 
strategię firmy i pożądane wyniki jej realizacji. Dla przykładu, jeśli rozważymy firmę, której działalność ukierunkowana jest na montaż komputerów z podzespołów, to takimi pojęciami są: Części - podzespoły do produkcji zestawów, Dostawa podzespołów do produkcji, Zasoby, Kapitał, Produkty, Sprzedaż wyrobów, Koszty, Przychody, Inwestycje. Każde z tych pojęć można interpretować jako zbiór encji albo zbiór obiektów, którym w planie biznesowym przypisano pewne atrybuty i charakterystyki, np. z pojęciem Produkt wiążą się takie atrybuty jak rodzaj produktu (zestawu), wielkość dysku zamontowanego w produkcie (zestawie), typ procesora itp. Jest to model konceptualny danych, który - skonstruowany i wynikający ze strategii (biznesplanu) - powinien również służyć do analizy i weryfikacji stopnia realizacji takiego biznesplanu. Zakres potrzeb związanych ze stopniem realizacji biznesplanu oraz analizy danych związanych z planem biznesowym i model konceptualny danych hurtowni są następnie podstawą do opracowania logicznego modelu danych, np. relacyjnego modelu danych, w którym wyróżniono fakty i wymiary. Dodatkowo, w rozważanym przykładzie, dzięki zaprojektowanemu modelowi danych hurtowni zgodnie z planem biznesowym, można hurtownię wykorzystać do przeprowadzenia procesu optymalizacji planu w oparciu o zgromadzone dane w hurtowni danych, a także do weryfikacji stopnia realizacji tego planu, w dowolnej chwili czasu, po implementacji hurtowni. Gdy w przyszłości biznesplan będzie zawierał inne istotne informacje biznesowe (nowe pojęcia) niż wyróżnione w planie, na podstawie którego utworzono model danych hurtowni, to powinna nastąpić modyfikacja modelu danych hurtowni zgodnie z modyfikacją biznesplanu. Należy również zauważyć, że budowa modelu danych w hurtowni oparta na biznesplanie nie tylko zawiera podstawowe dane związane z zarządzaniem strategią firmy, ale uwzględnia również cele i misję firmy, zgodnie z którą tworzy się biznesplan.

Ponadto firma jako system działania, zgodnie z inżynierią takich systemów (Konieczny, 1983), może być oceniana w oparciu o zmienne w czasie funkcje użyteczności i zabezpieczenia systemów, potrzeby i możliwości systemu, a także współczynniki dopasowania systemu do jego biznesowego otoczenia. Stosując podstawy inżynierii systemów działania, możliwe było wyprowadzenie teoretycznych zależności dla par systemów: hurtownia danych - firma, a także firma - jej biznesowe otoczenie, w formie następujących wektorów liczbowych:

- wykorzystania możliwości firmy w jej biznesowym otoczeniu w chwili $t$, przy czym wektor ten oznaczono symbolem $m^{F}(t)$,

- wektor pokrycia potrzeb otoczenia biznesowego firmy w chwili $t$ oznaczony symbolem $p^{F}(t)$ 
- wektor dopasowania firmy do jej biznesowego otoczenia w chwili $t$ oznaczony symbolem $d^{F O}(t)$,

- wektor współczynników wykorzystania możliwości hurtowni w firmie w chwili $t$ oznaczony symbolem $m^{H D}(t)$,

- pokrycia potrzeb użytkowników hurtowni danych $\mathrm{w}$ chwili $t \mathrm{w}$ formie wektora oznaczonego symbolem $p^{H D}(t)$,

- wektor dopasowania hurtowni do firmy oznaczony symbolem $d^{H F}(t)$ w dowolnej chwili czasu $t$.

Dokładne dowody teoretyczne i algorytmy wyznaczenia tych wektorów zostały zaprezentowane w literaturze (Śmiałkowska, 2009) i z racji ograniczonego charakteru niniejszego artykuły pominięto je. Podstawą do wyznaczenia wektorów współczynników $p^{F}(t), p^{H D}(t), d^{F O}(t), d^{H D}(t), m^{F}(t)$ oraz $m^{H D}(t)$ są dane przechowywane w hurtowni danych, na podstawie których można wyznaczyć intensywności przepływów materialnych, technicznych, technologicznych i informacyjnych między firmą a jej otoczeniem, a także intensywności przepływów informacyjnych miedzy firmą a hurtownią danych. Ponadto w celu wyznaczenia wektorów $p^{F}(t), p^{H D}(t), d^{F O}(t), d^{H D}(t), m^{F}(t)$ oraz $m^{H D}(t)$ w hurtowni danych powinny być przechowywane również dane niezbędne do obliczenia:

- tzw. cenności przepływów materialnych, technicznych i technologicznych w otoczeniu biznesowym firmy (Konieczny, 1983),

- cenności informacji przechowywanych w hurtowni danych firmy z wykorzystaniem koncepcji DWQ (Jarke i in., 2003),

- kosztów i nakładów ponoszonych z tytułu przepływów materialnych, technicznych i technologicznych w otoczeniu biznesowym firmy,

- produktywności lub efektywności przepływów materialnych, technicznych i technologicznych w otoczeniu biznesowym firmy (Śmiałkowska, 2009).

Teoretyczne możliwości wyznaczenia wektorów współczynników $p^{F}(t)$, $p^{H D}(t), d^{F O}(t), d^{H D}(t), m^{F}(t)$ oraz $m^{H D}(t)$, uwzględniające różne rodzaje przepływów między firmą a jej otoczenie biznesowych oraz firmą a hurtownią danych (np. przepływ ciągły, dyskretny, zdeterminowany, losowy, stacjonarny, niestacjonarny itp.) zostały zweryfikowane praktycznie w obszarze inżynierii systemów działania (Konieczny, 1983).

Wszystkie dane niezbędne do oceny dopasowania zarówno firmy do jej biznesowego otoczenia, jak również hurtowni do firmy, są na bieżąco gromadzone w dodatkowej warstwie metadanych adaptacyjnej hurtowni danych. 


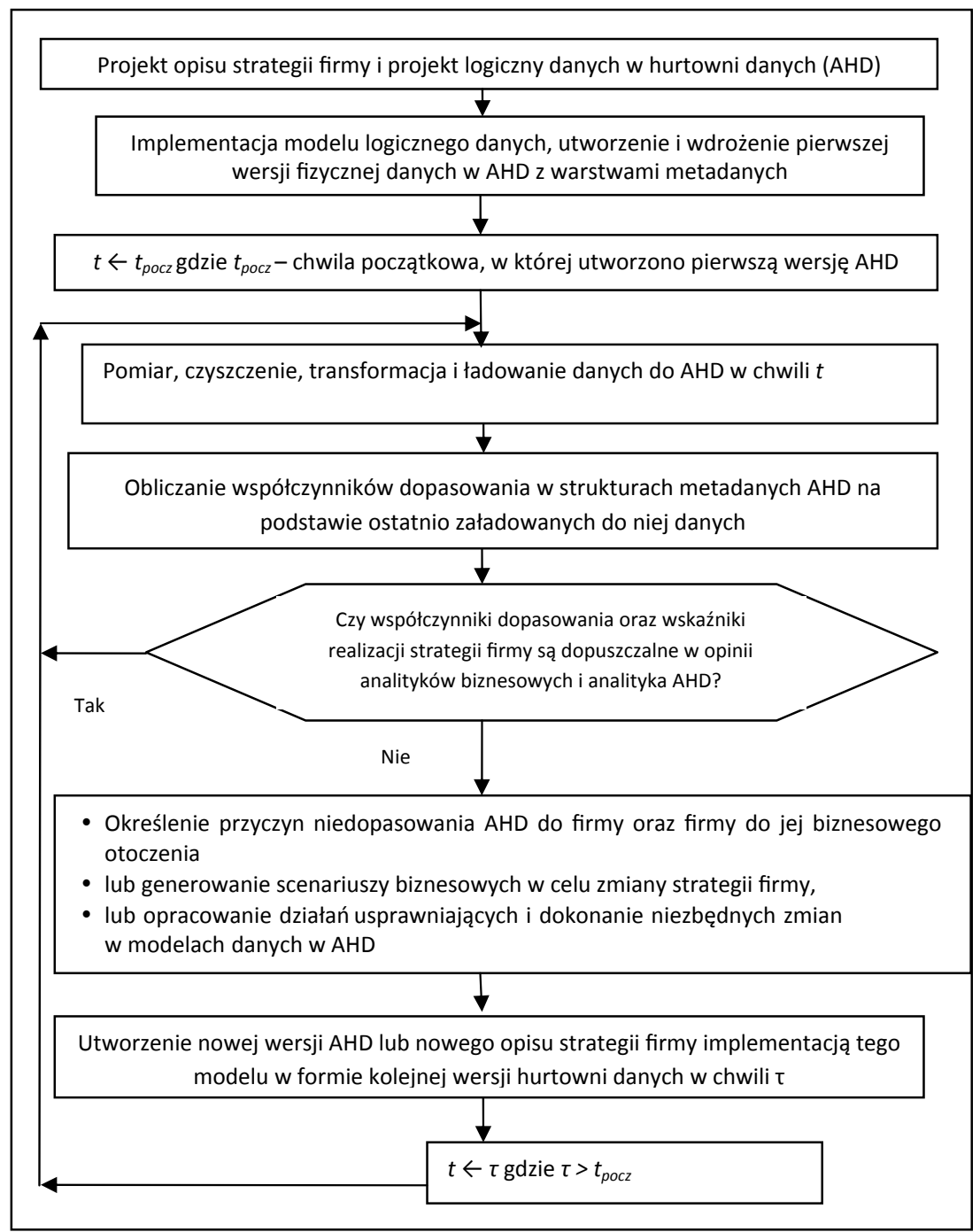

Rysunek 1. Proces adaptacji i dopasowania nadążnego hurtowni danych do nowych potrzeb informacyjnych firmy oraz dopasowania strategii firmy do jej otoczenia

Źródło: opracowanie własne.

Przykładowy model pojęciowo-funkcjonalny struktur danych niezbędny do obliczenia współczynników $m^{H D}(t), p^{H D}(t), d^{H F}(t), m^{F}(t), p^{F}(t)$ oraz $d^{F O}(t)$ w warstwie metadanych zaprezentowano w literaturze (Śmiałkowska, 2011).

Dostęp administracyjny do warstwy metadanych hurtowni pozwala na dopasowywanie hurtowni do zmiennych potrzeb informacyjnych firmy w kolejnych 
okresach osi czasu, co w rezultacie prowadzi do uwiarygodnienia (podwyższenia jakości) danych, na podstawie których są budowane, modelowane i weryfikowane scenariusze biznesowe, będące podstawą badania skutków planowanych zmian w strategii firmy. Hurtownia danych z tak zaprojektowanymi metadanymi umożliwi wówczas dodatkowo:

- bieżący pomiar i ocenę wskaźników dopasowania hurtowni do firmy w oparciu o struktury wewnętrzne hurtowni,

- przeprojektowywanie hurtowni (zmianę jej struktury), gdy jakość danych w niej przechowywanych jest niezadawalająca, a hurtownia nie jest dopasowana do firmy, dla której ją utworzono,

- permanentne zasilanie hurtowni danych nowymi źródłami danych, gdy tylko zaistnieje taka potrzeba.

W celu oceny, zgodnie z inżynierią systemów działania (Konieczny, 1983), dopasowania hurtowni danych do firmy, a właściwie do potrzeb jej użytkowników, niezbędny jest automatyczny pomiar i kontrola jakości przechowywanych danych w okresie bieżącej eksploatacji hurtowni. Jest to zgodne z koncepcją DWQ (Data Warehouse Quality) zaprezentowaną w literaturze (Jarke $\mathrm{i}$ in., 2003).

Ogólny schemat adaptacji wielowersyjnej hurtowni danych zaprezentowano na rysunku 1. Szczegółowy opis tego schematu wraz z weryfikacją i przypadkami jego użycia w firmie produkcyjnej lub usługowej zaprezentowano w pracy Śmiałkowskiej (2009). Ponadto adaptacyjna wielowersyjna hurtownia danych umożliwi:

- w modelowaniu biznesowym - zintegrowaną ocenę w aspektach systemowych (inżynieria systemów), prakseologicznych (sprawnego działania), cybernetycznych (zasilania informacyjnego, jakości danych), ekonomicznych (koszty, nakłady, produktywność, efektywność itp.) oraz matematycznych (formalnych, zgodnych z przyjętym modelem),

- uwzględnienie zmienności przyszłości w odniesieniu do przeszłości i teraźniejszości z użyciem wersjowania modelu danych w hurtowni,

- symulację i weryfikację różnych scenariuszy biznesowych w oparciu o zintegrowaną informację w celu wyboru takiego scenariusza, który zapewni osiągnięcie prognozowanej strategii na najlepszym poziomie przy istniejących lub prognozowanych możliwościach i potrzebach firmy,

- obserwację i ocenę modelu firmy w jej biznesowym otoczeniu, 
- wprowadzenie nowo pozyskanych źródeł danych z otoczenia firmy w celu uwzględnienia ich $\mathrm{w}$ procesach weryfikacji strategii firmy lub modelowania scenariuszy biznesowych,

- bieżącą weryfikację potrzeb użytkowników hurtowni, w tym również analityków modelujących lub weryfikujących scenariusze biznesowe.

Dodatkowo, adaptacyjną hurtownię danych cechują następujące właściwości:

- łączy w sobie modelowanie biznesowe $\mathrm{z}$ modelem danych,

- integruje wersjowanie z ewolucją schematu danych hurtowni,

- umożliwia automatyzację ,strojenia” oraz dopasowania hurtowni danych do nowych potrzeb dzięki przechowywaniu w warstwie metadanych hurtowni, ocen firmy w jej otoczeniu biznesowym oraz oceny strategii i hurtowni danych w kolejnych chwilach osi czasu,

- umożliwia analitykowi systemowemu, w formie interakcji, modyfikację modelu firmy, a administratorowi hurtowni wygenerowanie nowej wersji rzeczywistej hurtowni danych za pomocą utworzonego w tym celu oprogramowania działającego na metadanych hurtowni,

- umożliwia dopasowanie hurtowni nawet do gwałtownych zmian stanu, celów, misji i strategii firmy w jej zmiennym otoczeniu.

\section{Zastosowanie adaptacyjnej hurtowni danych do generowania scenariuszy biznesowych i modelowania strategii firmy}

Zaprezentowany model adaptacyjnej hurtowni danych stwarza warunki, w których można znacząco zmniejszyć lukę informatyczną w realizacji procesów oceny i wyboru strategii firmy poprzez możliwość budowy, modelowania i weryfikacji scenariuszy biznesowych, co schematycznie zaprezentowano na rysunku 2.

Dzięki zaprezentowanemu modelowi adaptacyjnej hurtowni danych analityk biznesowy może:

- wprowadzać zmiany w planowanych działaniach firmy,

- weryfikować skutki wynikające z tych zmian, co w rezultacie przyspieszy i ułatwi wprowadzanie innowacji biznesowych ukierunkowanych na zmianę profilu podstawowych działań firmy (profilu działalności, zasad współdziałania z otoczeniem, zmniejszenie kosztów działań, usprawnienie procesów realizowanych w firmie w sferze działań podstawowych, np. usług świadczonych przez firmę czy w sferze produkcji, zwiększenie możliwości sterowania procesami biznesowymi itp.), w tym definiowania strategii firmy. 


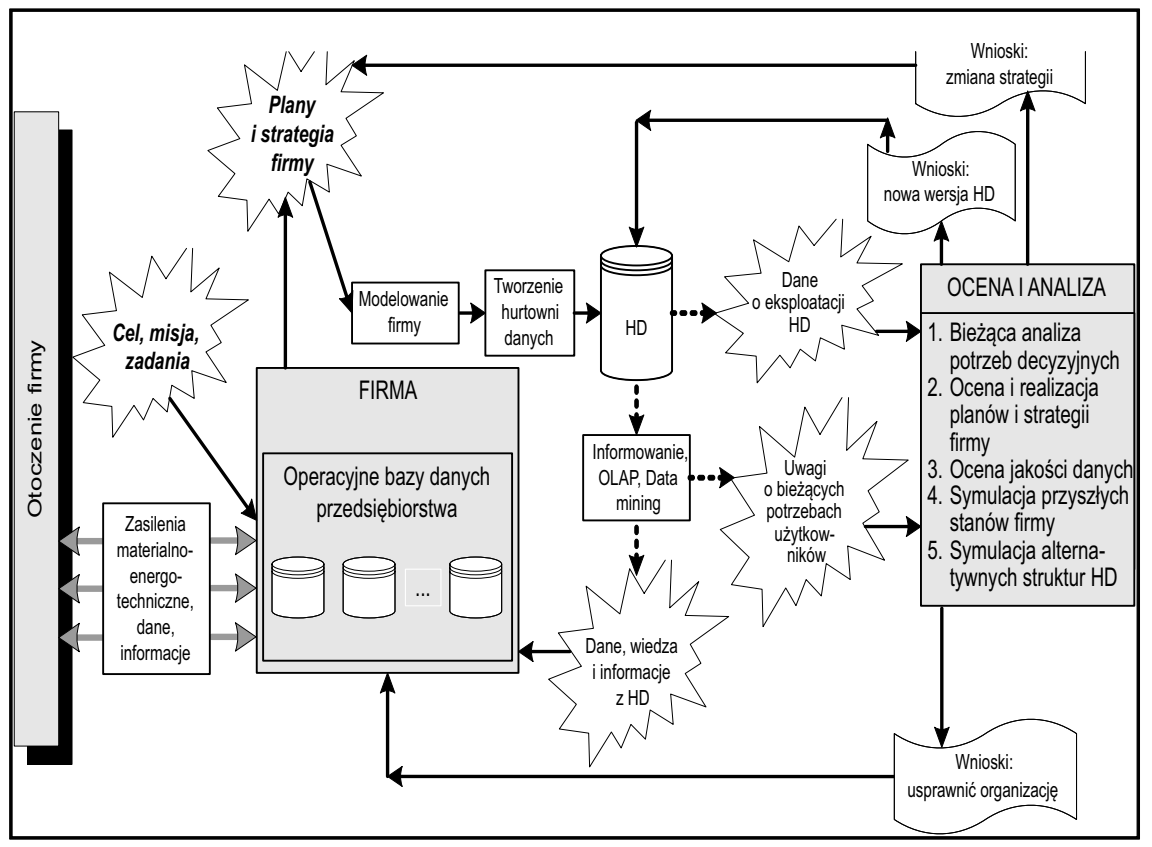

Rysunek 2. Wspomaganie procesów generowania wyników użycia scenariuszy biznesowych oraz oceny $\mathrm{i}$ wyboru strategii firmy - przykładowe zastosowanie Oznaczenia: $H D$ - adaptacyjna oraz wielowersyjna hurtownia danych.

Źródło: opracowanie własne.

Dodatkowo adaptacyjna i wielowersyjna hurtownia danych, która integruje niezbędne dane i dostarcza danych historycznych (np. danych o stanie przed wprowadzeniem usprawnień biznesowych i danych po ich wdrożeniu), umożliwia wprowadzanie kolejnych projektów i scenariuszy biznesowych, dzięki czemu można pomniejszyć lukę informacyjną w działaniach biznesowych.

Adaptacyjna hurtownia danych z oceną jakości danych w warstwie metadanych wskazuje analitykowi te dane w hurtowni, które są np. mało użyteczne, nieaktualne, nieświeże, złej jakości. Jest to ważny aspekt procesów budowy, modelowania i weryfikacji strategii biznesowych firmy, bowiem ogólnie można stwierdzić, że w oparciu o takie dane generowane są „gorszej” jakości lub nawet złe i niepoprawne scenariusze biznesowe.

Możliwość generowania alternatywnych scenariuszy biznesowych w oparciu o adaptacyjną hurtownię danych pozwala również, poprzez symulację, na poszerzenie wiedzy analityka biznesowego. Wówczas wiedza ta może być podstawą 
do wprowadzenia do hurtowni nowych źródeł danych po to, by je w przyszłości wykorzystać do budowy i modelowania nowych (przyszłych) scenariuszy biznesowych, a w konsekwencji nowych działań strategicznych firmy.

W tej koncepcji adaptacyjnej hurtowni danych istotnymi elementami obok narzędzi OLAP są również metody modelowania faktów, zdarzeń, stanów i procesów w firmie, metody materializacji (składowania) wyników modelowania „przyszłych" czy alternatywnych stanów firmy oraz metody odkrywania, eksploracji i wywodu wiedzy z danych.

Dodatkowo adaptacyjna hurtownia danych może być wyposażona w repozytorium metod i modeli, ułatwiających realizację takich czynności, jak wnioskowanie, eksploracja danych, odkrywanie wiedzy, rozwiązywanie zadań optymalizacyjnych itp. Odkrywanie wiedzy polega w tym przypadku na wyławianiu i reprezentowaniu ukrytych w danych reguł, wzorców i zależności. Odkryta wiedza może stanowić również nowe źródło danych. Takie metody mają szczególne znaczenie w procesie podejmowania decyzji, gdy odkryta wiedza może być materializowana w hurtowni danych.

Jednym z ważniejszych aspektów procesu generowania scenariuszy biznesowych jest dobór granuli czasu, innymi słowy określenie, jak często takie scenariusze biznesowe należy opracowywać. Dobór częstotliwości generowania oceny poziomu realizacji strategii firmy oraz częstotliwości tworzenia kolejnych scenariuszy biznesowych może być również wspomagany modelem hurtowni danych, zaprezentowanym w artykule. Jest to możliwe z tego względu, że przyczyną tworzenia scenariuszy biznesowych, a także oceny poziomu realizacji strategii firmy, są sytuacje, w których istnieje potrzeba podjęcia działań usprawniających firmę, a te zostaną wskazane przez adaptacyjną wielowersyjną hurtownię danych w formie współczynników dopasowania firmy do otoczenia, jakości danych zgromadzonych w hurtowni oraz wyników z realizacji strategii firmy. Takie potrzeby występują zwykle wówczas, gdy funkcjonowanie firmy w jej biznesowym otoczeniu wymaga działań niezależnie od tego, czy modyfikacja strategii firmy jest konieczna.

Dodatkowo adaptacyjna hurtownia danych ocenia jakość zgromadzonych w hurtowni danych (np. świeżość, przydatność, spójność, dostępność, poziom zagregowania i szczegółowości danych) i umożliwia w łatwy sposób rozszerzanie struktury danych o nowe źródła. Ta ostatnia możliwość jest realizowana dzięki wprowadzeniu do hurtowni nowej wersji danych z rozszerzoną strukturą.

Graficzną interpretację powyższych możliwości zastosowania zaproponowanego modelu adaptacyjnej wielowersyjnej hurtowni danych w formie funkcji, jakie 
są możliwe do zrealizowania w obszarze budowy, modelowania i weryfikowania scenariuszy biznesowych oraz strategii firmy, zaprezentowano na rysunku 3.

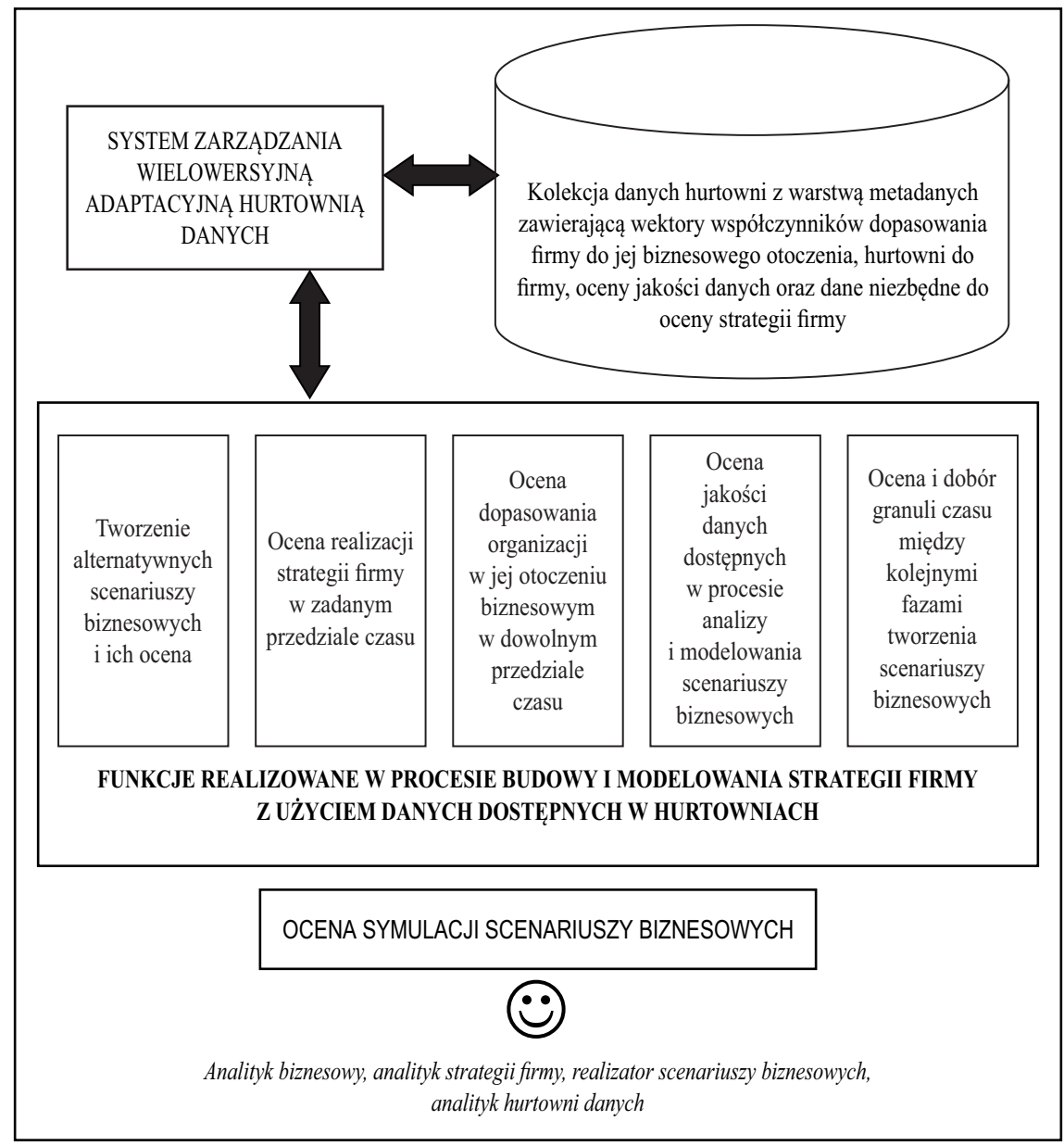

Rysunek 3. Funkcje realizowane w procesie budowy i weryfikacji scenariuszy biznesowych $\mathrm{w}$ systemie $\mathrm{z}$ aktywną hurtownią danych

Źródło: opracowanie własne.

Zaprezentowane funkcje adaptacyjnej hurtowni danych używane w ocenie poziomu realizacji strategii firmy oraz procesie budowy, modelowania i weryfikacji scenariuszy biznesowych czy w procesie zmiany lub modyfikacji strategii firmy, mogą być dzięki adaptacyjnej hurtowni wsparte również interpretacjami graficznymi. Dla przykładu, wyznaczane w hurtowni danych 
takie wielkości, jak współczynniki dopasowania firmy do otoczenia rynkowego, współczynniki pokrycia potrzeb użytkowników hurtowni, współczynniki wykorzystania możliwości hurtowni oraz parametry oceny strategii firmy $\mathrm{w}$ funkcji czasu mogą być udostępniane analitykowi biznesowemu w formie zgodnej z rysunkiem 4 .

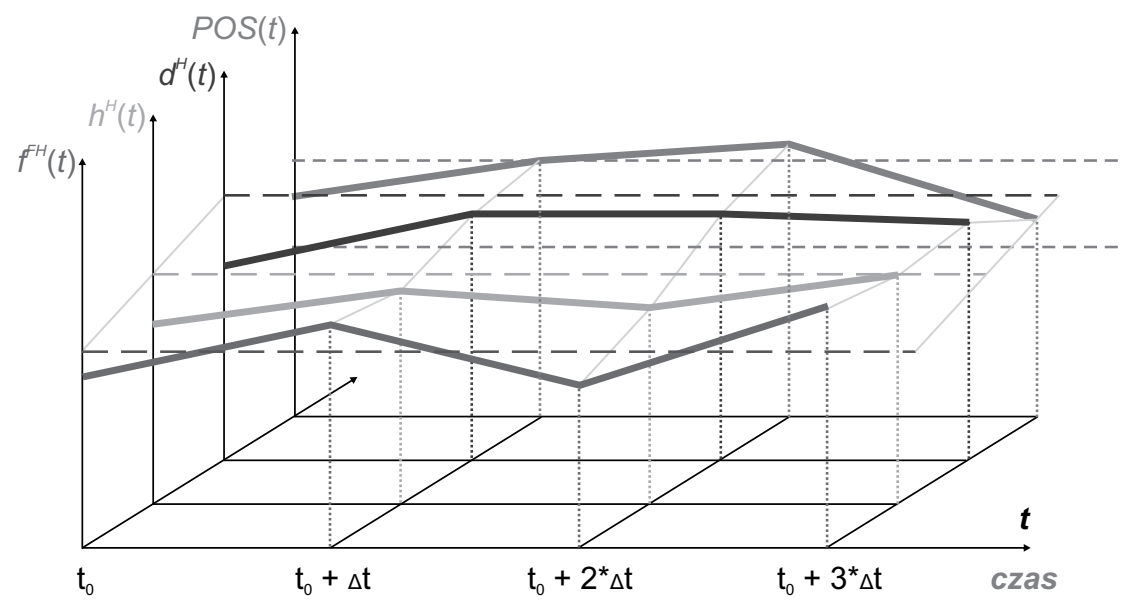

Rysunek 4. Przykładowe zastosowanie hurtowni danych do generowania wyników użycia scenariuszy biznesowych

Oznaczenia: $f^{F H}(t)$ - wspótczynnik dopasowania firmy do otoczenia rynkowego, $h^{H}(t)$ - współczynnik pokrycia potrzeb użytkowników hurtowni, $d^{H}(t)$ - współczynnik wykorzystania możliwości hurtowni, POS $(t)$ - parametry oceny strategii firmy.

Źródło: opracowanie własne.

\section{Podsumowanie}

Przedstawiona w artykule koncepcja adaptacyjnej hurtowni danych jest narzędziem wspomagającym procesy opracowywania scenariuszy biznesowych firmy, bowiem umożliwia:

- określenie chwili, w której konieczne jest opracowanie zmian biznesowych w firmie z punktu widzenia jej strategii,symulację przyszłych stanów firmy przy założonym planie wdrożenia scenariusza biznesowego,

- tworzenie scenariuszy biznesowych w oparciu o rzeczywisty model firmy w jej otoczeniu biznesowym odwzorowany w warstwie metadanych w adaptacyjnej hurtowni danych firmy, 
- określenie skutków wprowadzenia zmian w firmie wynikających z wdrożonego wcześniej scenariusza biznesowego w oparciu o dane rzeczywiste z funkcjonowania firmy, zgromadzone w hurtowni danych.

\section{Bibliografia}

Jarke M., Lenzerini M., Vassiliou Y., Vassiliadis P. (2003), Hurtownie danych. Podstawy organizacji i funkcjonowania, Wydawnictwa Szkolne i Pedagogiczne, Warszawa.

Konieczny J.(1983), Inżynieria systemów działania, WNT, Warszawa.

Śmiałkowska B., Dudek T. (2009), Ocena metod wersjowania baz i hurtowni danych, Studia i Materiały Polskiego Stowarzyszenia Zarządzania Wiedzą, t. 18, Bydgoszcz, s. $167-176$.

Śmiałkowska B. (2009), Metoda dopasowania hurtowni danych do zmiennych potrzeb informacyjnych przedsiębiorstwa, Wydawnictwo Uczelniane Zachodniopomorskiego Uniwersytetu Technologicznego w Szczecinie, Szczecin.

Śmiałkowska B. (2011), Adaptacja hurtowni danych do zmiennych potrzeb informacyjnych przedsiębiorstwa, „Studia Informatica Silesian University of Technology Press”, vol. 32, nr 2B (97), Materiały VII Konferencji Naukowej BDAS'2011, s. 443-454.

Wrembel R. (2007), Management of schema and data evaluation in multiversion data warehouse, Seria „Rozprawy” nr 411, Wydawnictwo Politechniki Poznańskiej, Poznań.

\section{CHOICE AND ESTIMATE OF ENTERPRISE STRATEGY WITH USE ADAPTIVE DATA WAREHOUSE}

\section{Summary}

The processes of defining and monitoring of the results of execution of enterprise strategy are complex and require access to appropriate data. From the point of view of computer-aided system these processes are require data collections that can be accessible in adaptation system with data warehouse. The article presents a model of the data warehouse with adaptive mechanism of the estimating of variables information about the functioning enterprise. This allow make an assessment of the current realization of enterprise strategy and run process the business scenarios. It also will allow for estimation the effects of possible changes of strategy of enterprise.

Translated by Bożena Śmiałkowska

Keywords: adaptive data warehouse, strategic decision support system 